\title{
Risk of Land Subsidence Related to Underground Karst Caves and Solutions, North-South Vietnam Expressway
}

\author{
Phi Hong Thinh ${ }^{1, *}$, Nguyen Thai Linh ${ }^{1}$, Dang Hong Lam ${ }^{1}$ and Phi Truong Thanh ${ }^{2}$ \\ University of Transport and Communications, Hanoi, Vietnam \\ Hanoi University of Natural Resources and Environment, Hanoi, Vietnam \\ Correspondence: thinhph@utc.edu.vn
}

\begin{abstract}
Received:

13 July 2021

This paper assesses the risk of land subsidence related to the underground Karst caves at the section Km55+660- Km55+690 of North-South Vietnam Expressway by finite element method using PLAXIS 2D V.8.5 software. The research results show that there is a risk of

Accepted: 25 September 2021 collapsing the ceiling of the underground Karst caves due to the impact of the embankment process and the vehicle load. The research results also show that the vertical displacement is

Published:

31 January 2022 larger than the allowable residual settlement according to Vietnamese standard; it is necessary to take the soft soil improvement to achieve the allowable residual settlement. Several construction solutions are proposed to prevent the risk of land subsidence in the research section. In particular, flyover through the section with underground Karst caves is the most suitable solution.
\end{abstract}

Keywords: Karst; Land subsidence; Sinkhole; North-South Vietnam expressway

\section{Introduction}

The section Km55+660- Km55+690 of North-South Vietnam Expressway is located in Phong Son commune, Phong Dien district, Thua Thien Hue province, Vietnam (Fig.1). During the geotechnical investigation for technical design and construction of the Expressway carried out in 2020 and 2021 at the section, underground karst caves were met at the location of boreholes $\mathrm{BH} 01, \mathrm{BH} 02$ and $\mathrm{BH} 03$ (Figs. 3 and 4). To ensure the stability of the Expressway during construction and exploitation, it is necessary and urgent to assess the risk of land subsidence related to the underground Karst caves at the section in order to take suitable solutions to prevent the risk of land subsidence.

Researches on land subsidence in the karst regions began to be noticed at the end of the $20^{\text {th }}$ century. Most notably, some researches by Milanovic (2000), Waltham and Lu (2007), Waltham (2008), (Awadh et al., 2013), and Abdula (2021). These researches have introduced the concept, definition, and classification of the land subsidence in the Karst regions and Karst morphologies. The existence of the underground Karst space (open cracks, cavities and caves) due to chemical dissolution and washing of Karst rocks into the cracks and fractured zones is considered as the initial premise of the land subsidence. In addition, the authors also pointed out that the land subsidence caused by material from covered soil layers being swept into the underground Karst space is very common, occurs suddenly and is the most dangerous form of the risk, while the ceiling collapsing of the underground Karst space is

DOI: $\underline{10.46717 / i g j .55 .1 A .3 M s-2022-01-22 ~}$ 
very rare and occurs for a very long time. In Vietnam, Karst occupies about $20 \%$ of the land area and is mainly concentrated in the North (Fig. 1). The land subsidence has occurred and is latent in many Karst regions of Vietnam (Fig. 2). Faced with that situation, researches on this hazard have been paid attention and have achieved remarkable results. The most significant are the researches of Vietnam Institute of Geosciences and Mineral resources (2005), Duc and Binh (2012), Institute of Geological Sciences (2014), Thinh et al. (2020). In these researches, the causes of land subsidence are determined, including 2 groups of factors: a group of slow-changing factors (Karst space, geological structure, tectonics) and another group of fast-changing factors (underground extraction, coal mining, increase in static load, sewage system failure, seasonal fluctuations of groundwater level, tides, earthquake...). Specifically, factors of geology-petrology, geomorphology-neotectonics, hydrogeology-engineering geology are considered as "necessary" conditions, while other factors changing natural dynamics of groundwater and factors acting on the surface are "sufficient" conditions to cause the land subsidence.

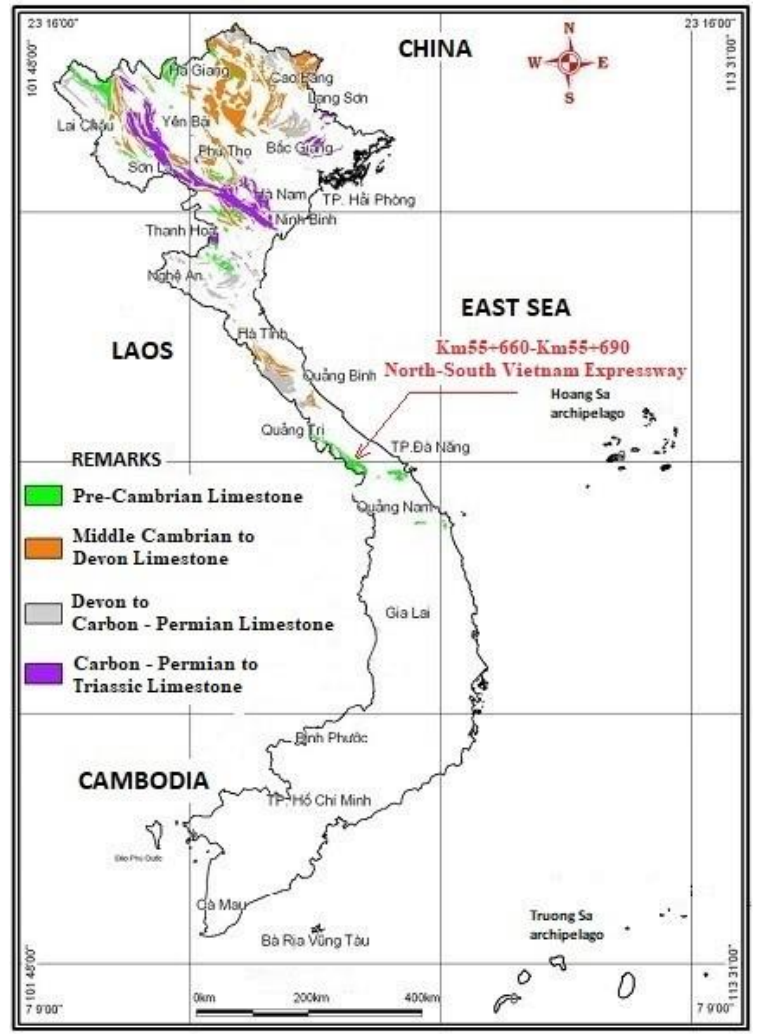

Fig 1. Limestone distribution map in Vietnam (Vietnam Institute of Geosciences and Mineral resources, 2005)

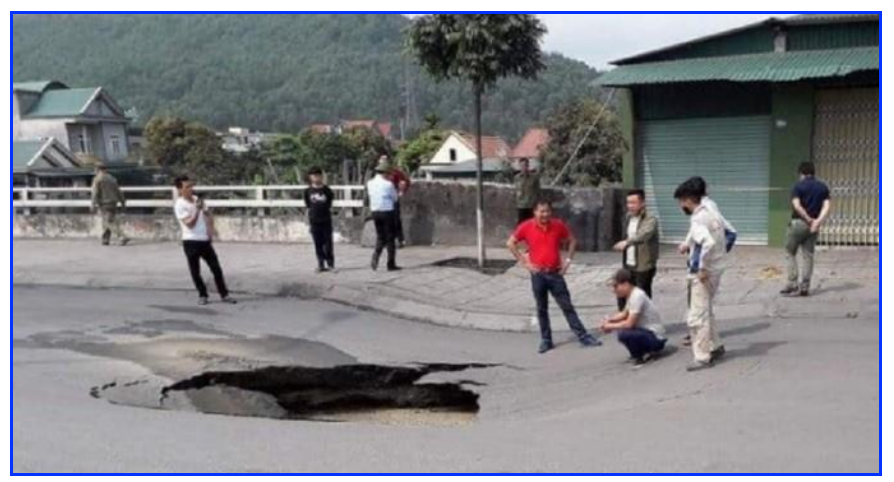

Fig. 2. A sinkhole at national highway 18, Quang Ninh province, Vietnam, on March 01, 2019 


\section{Materials and Methods}

\subsection{Materials}

Nine boreholes with the depth of $12 \mathrm{~m}$ to $16 \mathrm{~m}$ were carried out at the research section by Hung Nghiep Construction Consulting Limited Liability Company (HNCCLLC) in 2020 and 2021 (Figs. 3 and 4). Forty five (45) soil and rock samples were taken from these boreholes for laboratory testing. The stratigraphy of the section from Km55+660 to Km55+690 includes 04 soil and rock layers as follows:

- Layer 1: Soft, greenish grey sandy clay with gravel

- Layer 2: Stiff to very stiff, grey, yellowish grey sandy clay with gravel

- Layer 3: Grey, slightly weathered, fractured limestone

- Layer K: Underground karst cave

- Layer 4: Soft to firm, grey sandy clay with gravel

Table 1. Physical, mechanical properties of soil and rock layers (HNCCLLC, 2020 and 2021)

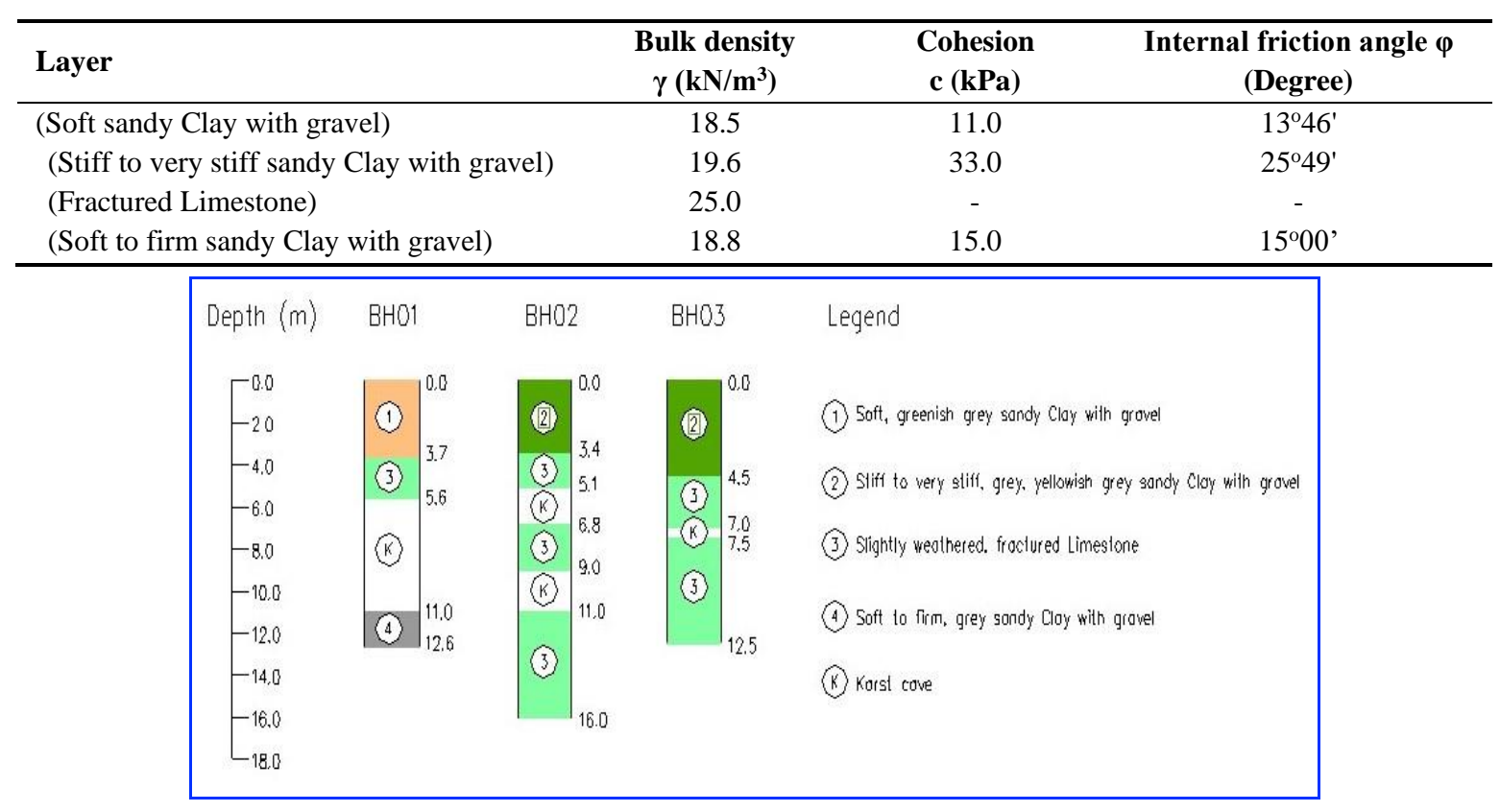

Fig. 3. Boring logs at the boreholes that meet underground Karst caves (HNCCLLC, 2020 and 2021)

Groundwater table is determined at the top of the underground Karst caves, from the depth of 5.1 to $5.6 \mathrm{~m}$. Loads from embankment and vehicles on the ground at the research section are calculated and listed in Table 2 below:

Table 2. Loads from embankment and vehicles on the ground (HNCCLLC, 2021 and 22 TCN 262-

2000)

\begin{tabular}{lcc}
\hline Factors & $\begin{array}{c}\text { Height x width; } \\
\text { \& slope of the expressway }\end{array}$ & Parameters \\
\hline Embankment & $4.5 \mathrm{~m} \times 12.0 \mathrm{~m} ;$ & $\gamma=19.5 \mathrm{kN} / \mathrm{m}^{3} ; \mathrm{c}=35 \mathrm{kPa} ;$ \\
(sandy Clay with gravel) & slope of 1.5 & $\varphi=25^{0}$ \\
Load of vehicles & - & 30 tons \\
\hline
\end{tabular}




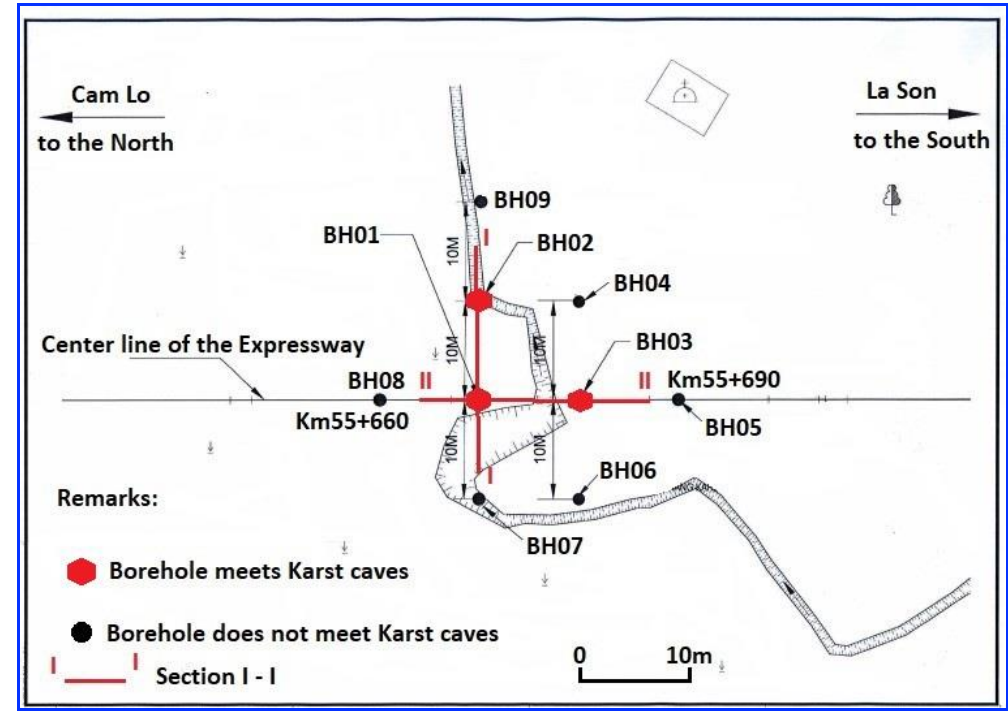

Fig. 4. Sketch of borehole locations in the section Km55+660- Km55+690 of North- South Vietnam Expressway (HNCCLLC, 2020 and 2021)

\subsection{Methods}

The factors causing land subsidence in the Karst regions can be divided into two main groups: a group of slow-changing factors and another group of fast-changing factors (Fig. 5).

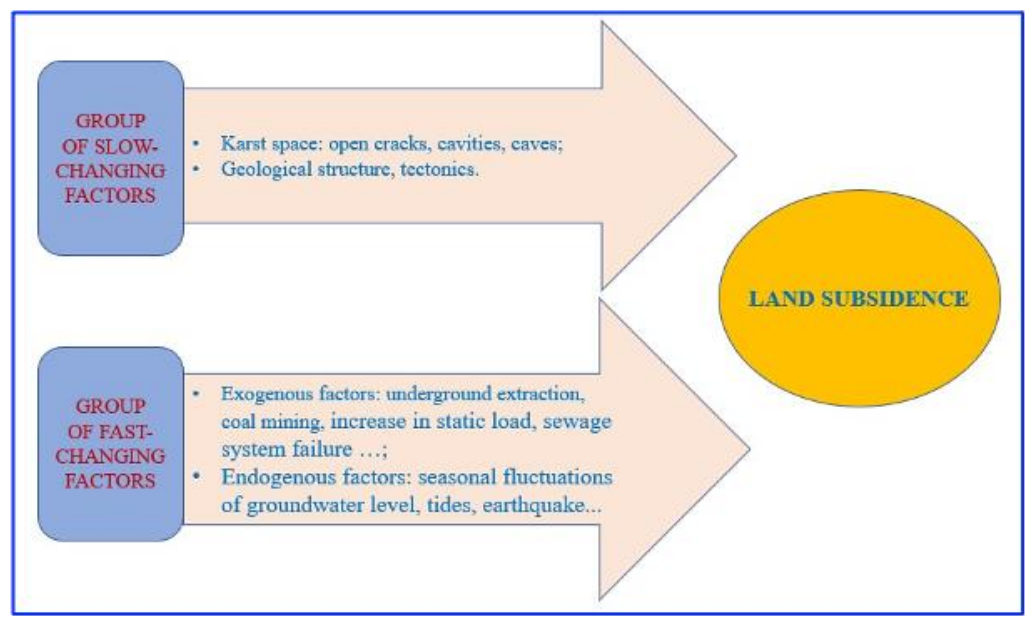

Fig. 5. The factors that cause land subsidence in the research section (Institute of Geological Sciences, 2014)

The phenomenon of land subsidence is modeled; Vertical and horizontal displacements due to increased loads from embankment and vehicles are calculated by the finite element method using PLAXIS 2D V.8.5 software. Mohr-Coulomb and Linear Elastic models were selected for materials.

\section{Results and Discussion}

\subsection{The Group of Slow Changing Factors}

Phong Son commune, Phong Dien district, Thua Thien Hue province has limestone bedrock. The presence of limestone is a favorable condition for the existence and development of the underground Karst space (open cracks, cavities, and caves) due to the chemical dissolution and washing of limestone 
into the fractured and cracked zones and is considered as the initial premise of the risk of land subsidence at the research section. In addition, researches in the world and in Vietnam show that land subsidence caused by material from covered soil layers being swept into the underground Karst space is very common, occurs suddenly, and is the most dangerous form of the risk, while the ceiling collapsing of the underground Karst space is very rare and occurs for a very long time.

\subsection{The Group of Fast Changing Factors}

The land subsidence will hardly occur without stimulating factors, mainly due to exogenous and endogenous causes such as: increase in water flow to covered soil layers; groundwater level goes down; mining activities; change of the vegetation cover; noise; increase in static load from construction works, dynamic load from vehicles, filling material, and seasonal fluctuations of groundwater level, earthquake... However, most of the above-mentioned stimulating factors have not been identified clearly in the section from Km55+660 to Km55+690, so there is no firm basis to assess the influence of these factors on the possibility of the land subsidence at the research section, which should be continued study. The assessment results on the risk of land subsidence related to underground Karst caves due to the influence of loads from embankment and vehicles. The influence of embankment and vehicle loads on the risk of land subsidence is considered at 02 geotechnical sections meeting underground Karst caves, the sections No. I-I and II-II (Fig. 4), considering the most unfavorable case when the caves are interconnected by finite element method using PLAXIS 2D V.8.5 software.

\subsubsection{Input parameters}

The input parameters for the software are shown in Table 3 below. In there, Mohr-Coulomb and Linear Elastic models were selected for soil and rock materials; bulk density, cohesion and internal friction angle of the layers were taken according to the geotechnical investigation results carried out by HNCCLLC in 2020 and 2021; Young modulus and Poisson ratio were calculated and taken according to PLAXIS Software User Manual (Figs. 6 and 9).

Table 3. The input parameters for PLAXIS 2D V.8.5 software

\begin{tabular}{|c|c|c|c|c|c|c|}
\hline Layer & $\begin{array}{c}\text { Material } \\
\text { model }\end{array}$ & $\begin{array}{c}\text { Bulk density } \\
\gamma\left(\mathbf{k N} / \mathbf{m}^{3}\right)\end{array}$ & $\begin{array}{c}\text { Cohesion } \\
\text { c }(\mathbf{k P a})\end{array}$ & $\begin{array}{c}\text { Internal } \\
\text { friction angle } \varphi \\
\text { (Độ) }\end{array}$ & $\begin{array}{c}\text { Young } \\
\text { modulus } \\
\text { E }(\mathbf{k P a}) \\
\end{array}$ & $\begin{array}{l}\text { Poisson } \\
\text { ratio v }\end{array}$ \\
\hline 1 & $\begin{array}{c}\text { Mohr } \\
\text {-Coulomb }\end{array}$ & 18.5 & 11.0 & $13^{\circ} 46^{\prime}$ & 2,000 & 0.35 \\
\hline 2 & $\begin{array}{c}\text { Mohr } \\
\text {-Coulomb }\end{array}$ & 19.6 & 33.0 & $25^{\circ} 49^{\prime}$ & 6,000 & 0.30 \\
\hline 3 & $\begin{array}{l}\text { Linear } \\
\text { Elastic }\end{array}$ & 25.0 & - & - & 70,000 & 0.25 \\
\hline 4 & $\begin{array}{c}\text { Mohr } \\
\text {-Coulomb }\end{array}$ & 18.8 & 15.0 & $15^{\circ} 00^{\prime}$ & 5,000 & 0.30 \\
\hline Embankment & $\begin{array}{c}\text { Mohr } \\
\text {-Coulomb }\end{array}$ & 19.5 & 35.0 & $25^{\circ} 00^{\prime}$ & 30,000 & 0.30 \\
\hline
\end{tabular}

Groundwater table is determined at the top of the underground Karst caves, at the depth of 5.1m. 


\subsubsection{Modeling steps}

- Step 1: Modeling the problem into PLAXIS software

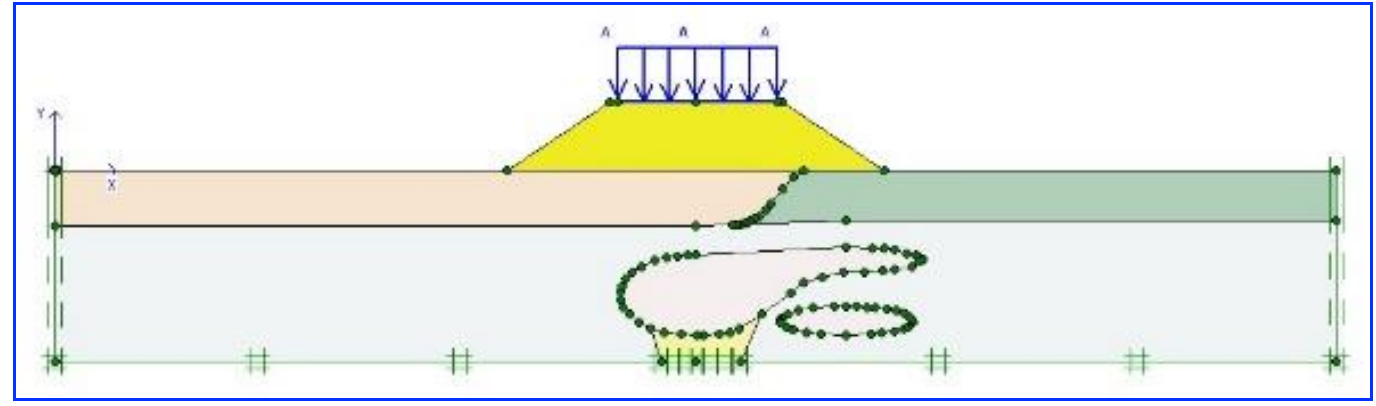

Fig. 6. Modeling the problem corresponding to the geotechnical section I-I into PLAXIS software

- Step 2: Meshing a 15-node triangle element

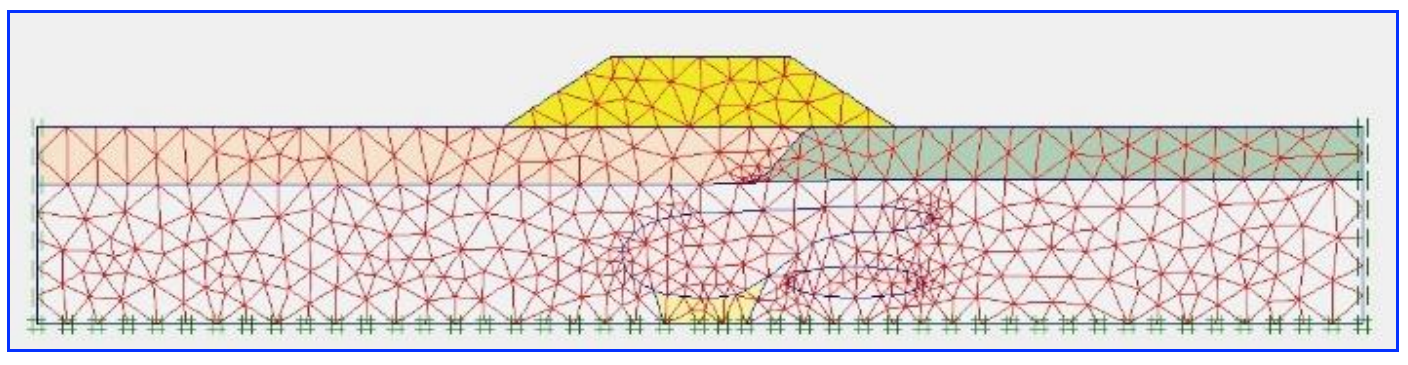

Fig. 7. Meshing a 15-node triangle element corresponding to the geotechnical section I-I

- Step 3: Declaring the groundwater table and bulk density of the soil and rock

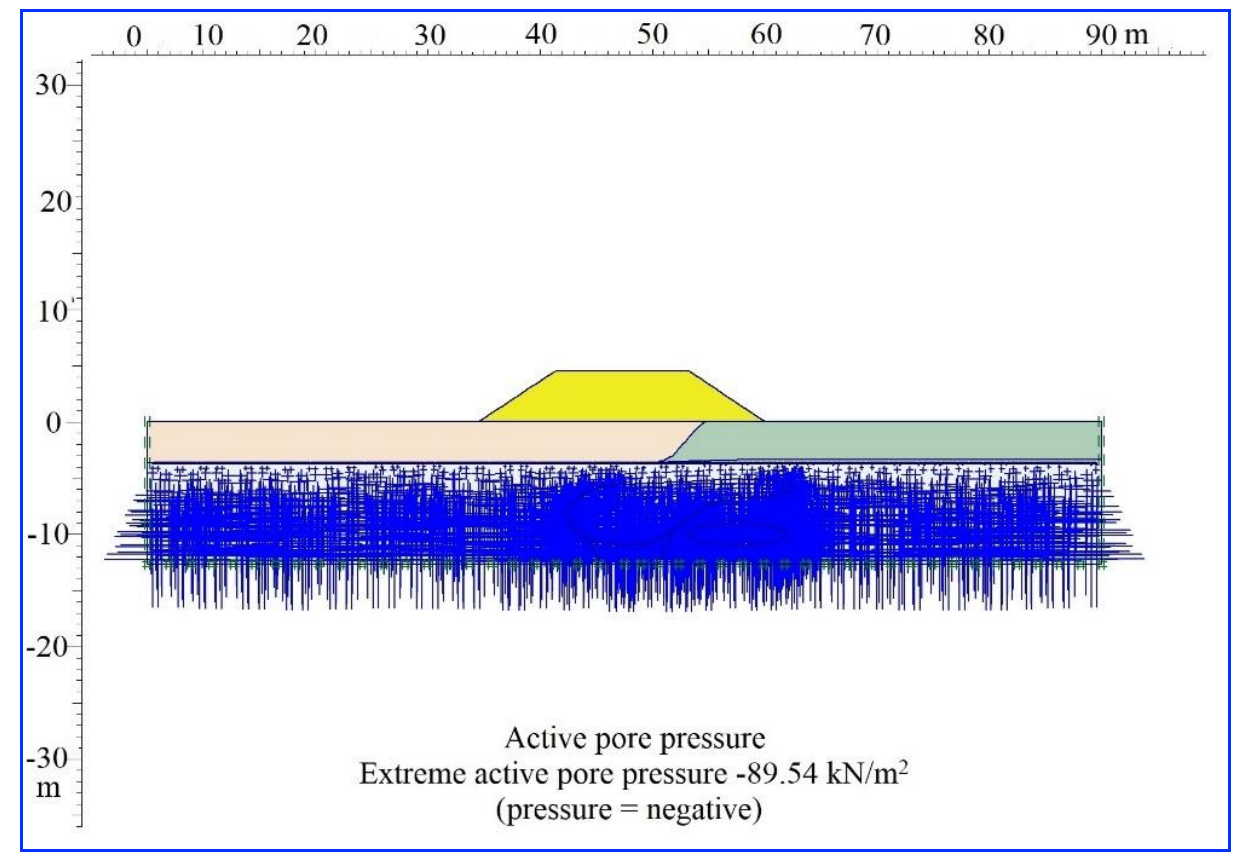

Fig. 8. Declaring the groundwater table and bulk density of the soil and rock layers corresponding to the geotechnical section I-I 
- Step 4: Declaring the construction process

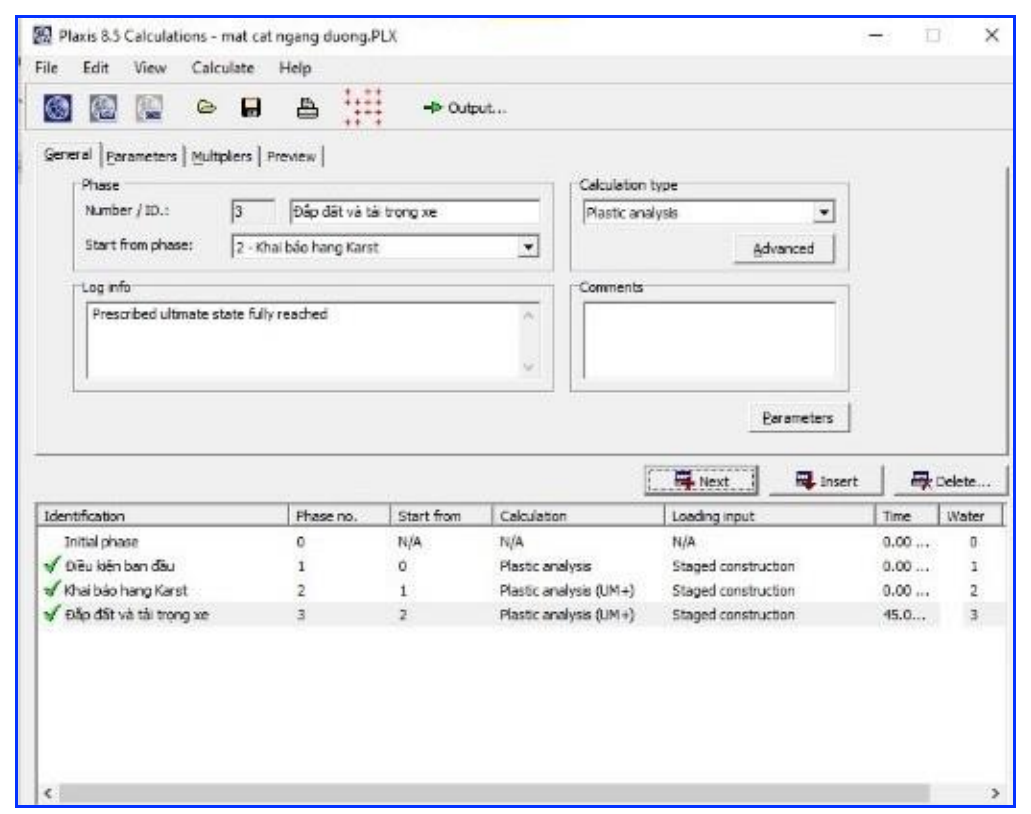

Fig. 9. Declaring the construction process corresponding to the geotechnical section I-I; Modeling steps from 1 to 4 are also performed similarly for the geotechnical section II-II.

- Step 5: Outputting calculation results

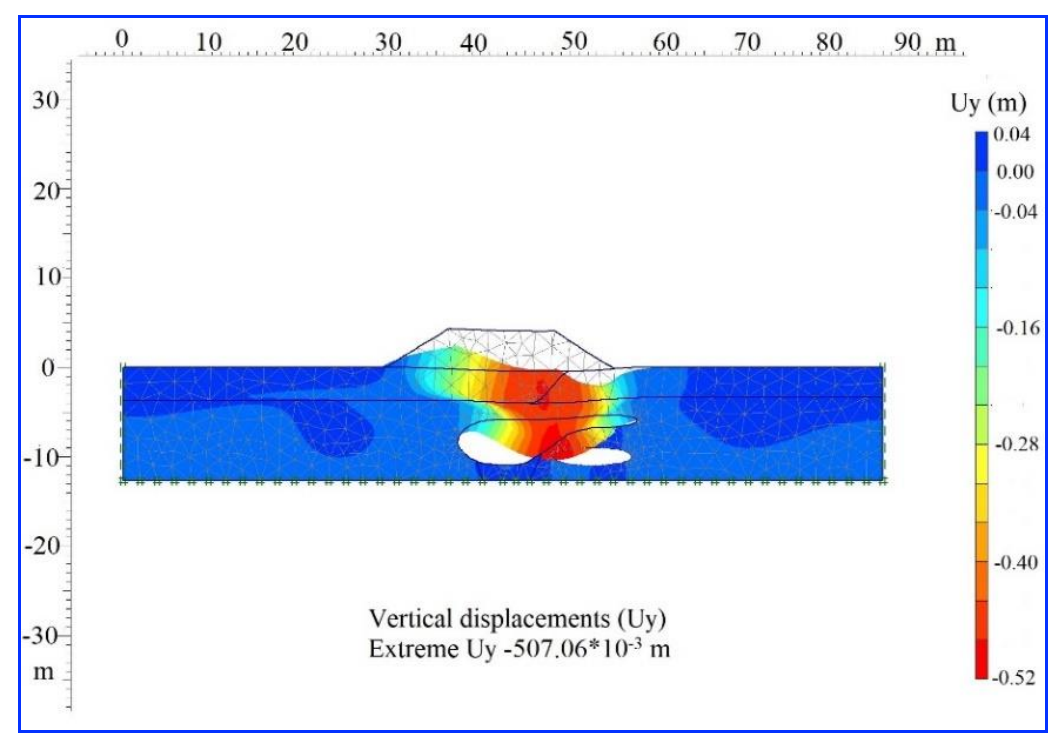

Fig. 10. Vertical displacement (Uy)/Settlement (S) of the ground corresponding to the geotechnical section I-I (The calculation results show that maximum settlement $S_{\max } I-I$ is $50.7 \mathrm{~cm}$ )

According to the Manga \& Wang (2015), at shear strains from $10^{-4}$ to $10^{-3}$, brittle rocks, sediments, and soils show permanent deformation. At even greater shear strains of $10^{-2}$ (equivalent to $1.0 \%$ ), failure occurs. The research results of Manga \& Wang are also consistent with the research results of Lam and Thinh (2020). Results of uniaxial compression test in the laboratory according to Vietnamese standard TCVN 10324:2014 on limestone samples taken from National Highway 3B, the section through Bac Kan province of Vietnam showed that the incremental shear strains at failure (ISS ${ }_{\max }$ ) of the limestone samples were in the range of $1.0 \%$ to $1.7 \%$. 


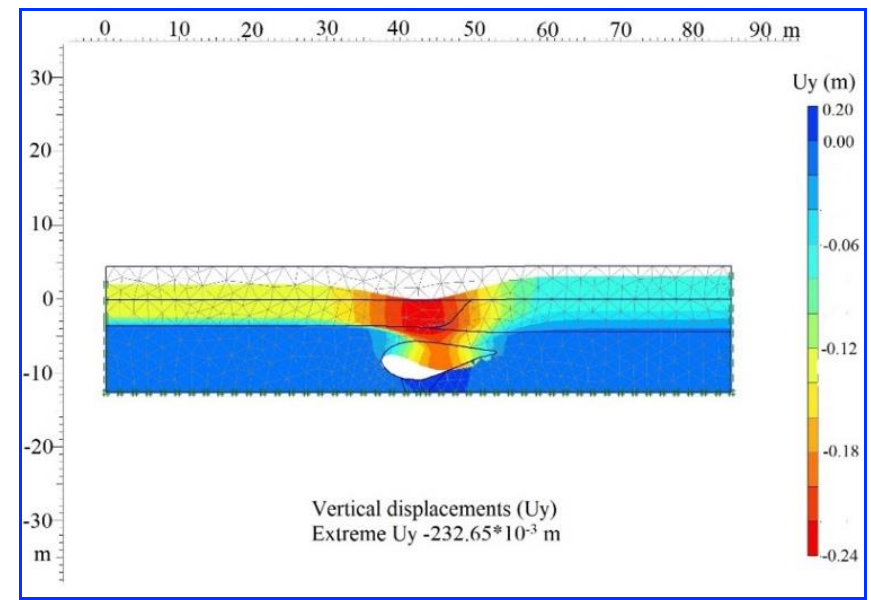

Fig. 11. Vertical displacement (Uy)/Settlement (S) of the ground corresponding to the geotechnical section II-II (The calculation results show that maximum settlement $S_{\max }$ II-II is $23.3 \mathrm{~cm}$ )

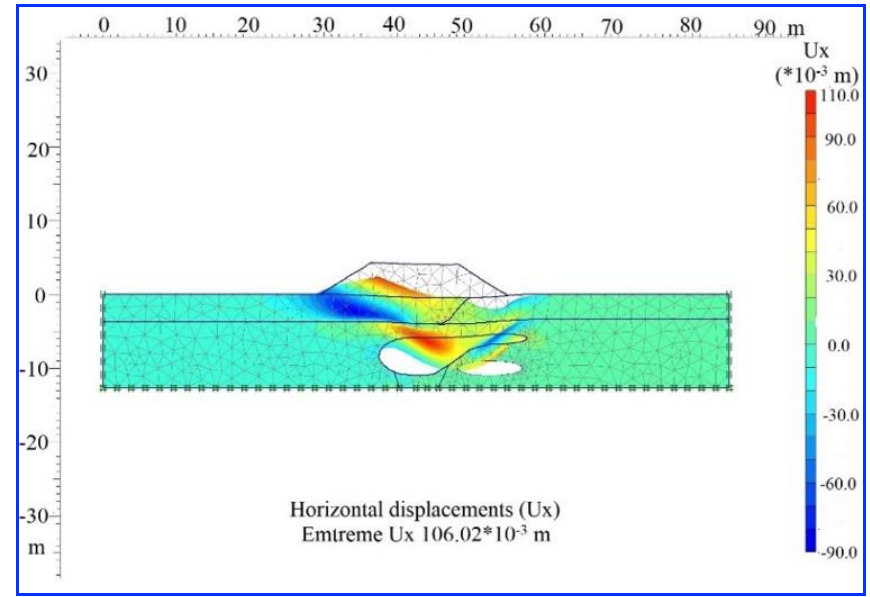

Fig. 12. Horizontal displacement $(\mathrm{Ux} / \mathrm{H})$ of the ground corresponding to the geotechnical section $\mathrm{I}-\mathrm{I}$ (The calculation results show that maximum horizontal displacement $\mathrm{H}_{\max } \mathrm{I}-\mathrm{I}$ is $10.6 \mathrm{~cm}$ )

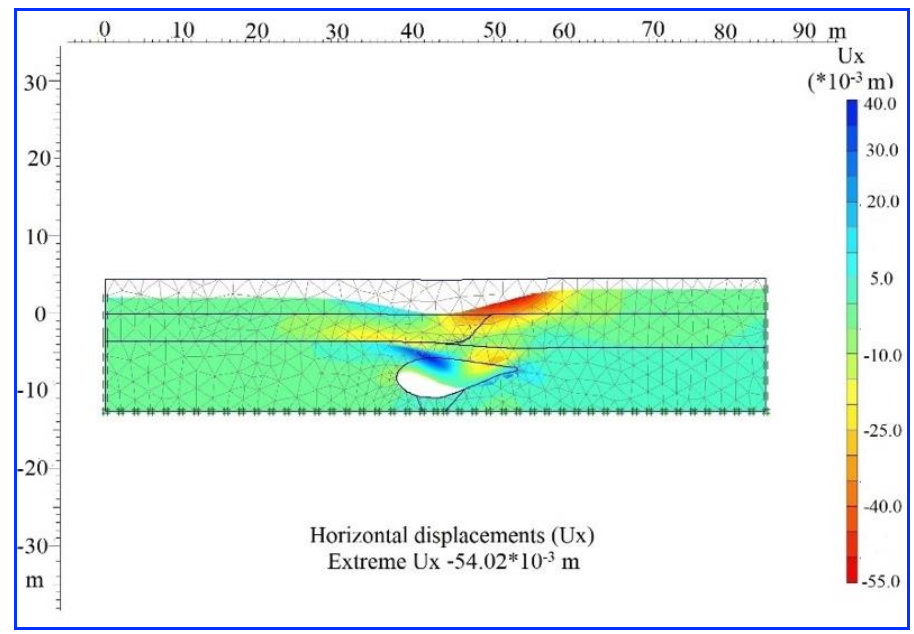

Fig. 13. Horizontal displacement $(\mathrm{Ux} / \mathrm{H})$ of the ground corresponding to the geotechnical section II-II (The calculation results show that maximum horizontal displacement $\mathrm{H}_{\max }$ II-II is $5.4 \mathrm{~cm}$ ) 


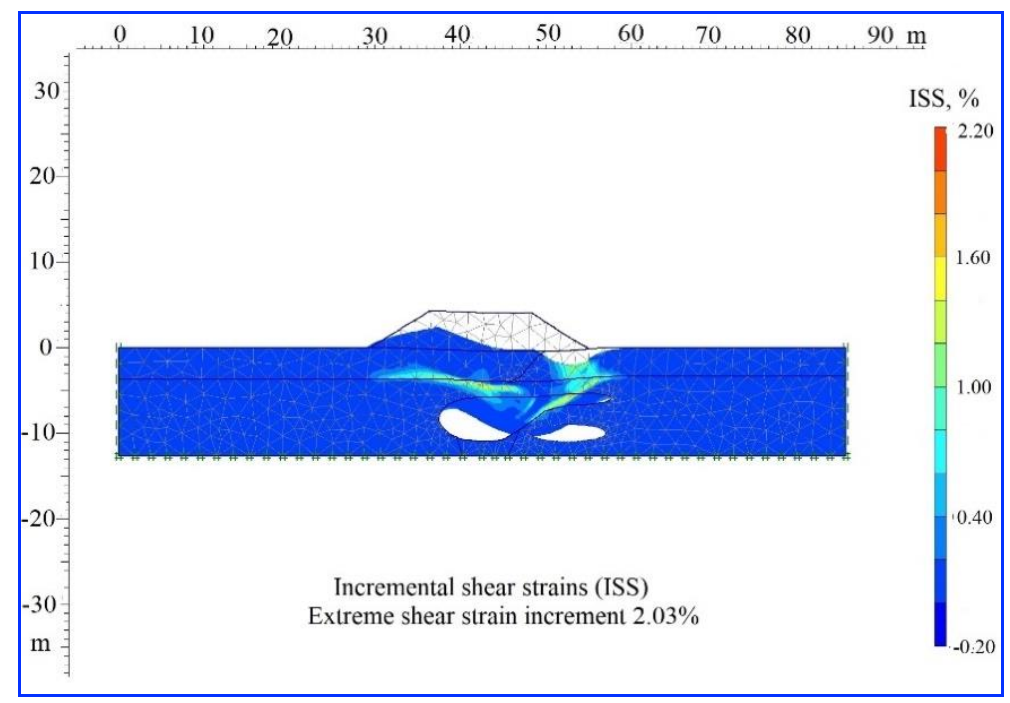

Fig. 14. Incremental shear strain (ISS) at the geotechnical section I-I. (The calculation results show that maximum incremental shear strain ISS $_{\max } \mathrm{I}-\mathrm{I}$ is $2.03 \%$ )

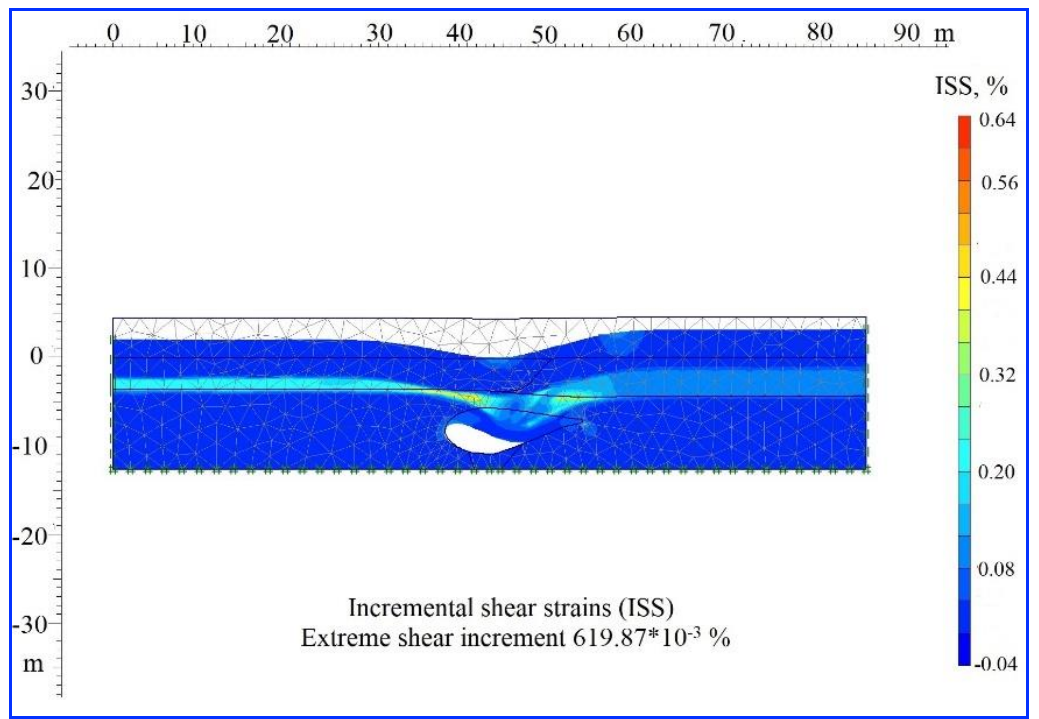

Fig. 15. Incremental shear strain (ISS) at the geotechnical section II-II. (The calculation results show that maximum incremental shear strain ISS $_{\max }$ II-II is $0.62 \%$ )

At the geotechnical section I-I: The incremental shear strain reached the maximum value of $2.03 \%$ at the top of the underground Karst cave, showing that there is a risk of collapsing the ceiling due to the influence of the embankment process and vehicle load. It is necessary to have solutions to prevent the risk of land subsidence (Figs. 14 and 15). At the geotechnical section II-II: The incremental shear strain reached the maximum value of $0.62 \%$ at the ceiling position of the limestone layer above the underground Karst cave, showing that there is no danger of collapsing the ceiling due to the influence of the embankment process and vehicle load.

Calculated results of vertical and horizontal displacements of the ground due to the influence of embankment and vehicle load the maximum vertical and horizontal displacements of the ground due to the influence of embankment and vehicle loads at 2 geotechnical sections I-I and II-II are shown (Figs. $10,11,12$ and 13). 
Table 4. Calculated results of the maximum vertical and horizontal displacement of the ground due to the influence of embankment and vehicle loads at 02 geotechnical sections I-I and II-II

\begin{tabular}{|c|c|c|c|c|}
\hline Section & $\begin{array}{c}\text { Max. } \\
\text { vertical displacement } \\
S_{\max }(\mathrm{cm}) \\
\end{array}$ & $\begin{array}{c}\text { Max. horizontal } \\
\text { displacement } \\
H_{\max }(\mathbf{c m})\end{array}$ & $\begin{array}{l}\text { Allowable residual settlement } \\
\text { [S] }(\mathrm{cm}) \text { according to } \\
22 \text { TCN } 262-2000\end{array}$ & Conclusion \\
\hline Section I-I & 50.7 & 10.6 & 20 & $\begin{array}{c}\text { Not } \\
\text { achieved }\end{array}$ \\
\hline Section II-II & 23.3 & 5.4 & 20 & $\begin{array}{c}\text { Not } \\
\text { achieved }\end{array}$ \\
\hline
\end{tabular}

Note: Allowable residual settlement according to 22 TCN262 - 2000, section II.2.3, at the location near the culvert, allowable residual settlement must be smaller than $20 \mathrm{~cm}$. Thus, with the maximum vertical displacement (settlement) of $50.7 \mathrm{~cm}$ at the geotechnical section I-I and $23.3 \mathrm{~cm}$ at the geotechnical section II-II, both are greater than the allowable residual settlement, it is necessary to take the soft soil improvement to achieve the allowable residual settlement.

\subsection{Solutions to Prevent the Risk of Land Subsidence in the Research Section}

Some of the following construction solutions can be applied to prevent the risk of land subsidence in the research section:

- Knocking down the underground Karst caves near the ground surface with explosive energy or dynamic loads and then backfilling the hole with soil and rock materials. The hole should be filled in layers and compacted especially the last 2-3 layers. After backfilling, it is necessary to continue monitoring the backfilling area for a period of one year.

- Applicability assessment: At the research section, the underground Karst caves are located at a fairly great depth; the ceiling of the caves is located at a depth of $5.1 \mathrm{~m}$ to $9.0 \mathrm{~m}$, on which is a layer of limestone with a thickness of from $1.7 \mathrm{~m}$ to $2.5 \mathrm{~m}$. If this solution is applied, the construction will be difficult due to the great depth; the procedure for getting permission to use explosives is quite complicated and takes a long time. If using dynamic loads (hammer ...) to knock down the rock layer above the ceiling of the cave, it will cause concussion and loud noise. Besides, the thickness of the backfilling soil after collapsing the cave is quite large; it is difficult to ensure the compaction to achieve the allowed residual settlement, and necessary to monitor settlement for a long time, affecting the overall progress of the project. Therefore, this solution has a poor feasibility.

- Drilling and grouting clay, cement and bitumen to fill cracks and caves.

- In the research section, the underground Karst caves have a rather large height, from $0.5 \mathrm{~m}$ to $5.4 \mathrm{~m}$, the spatial distribution has not been fully studied, so the quantitative calculation of grout volume is not accurate. After grouting, it is still necessary to take the soft soil improvement to achieve the allowable residual settlement. One of the most suitable soft soil improvement method in the research section is the point foundation shown in the research of Son et al. (2020).

- In order to accurately determine the grout volume, it is necessary to accurately determine the spatial distribution of the underground Karst system in the research section by geophysical methods.

- If the underground Karst caves have small size, this solution is highly feasible.

- If the underground Karst caves are large and connected on a large scale, this solution cannot be applied.

- Flyover through the section with underground Karst caves.

- This is a solution with a high feasibility, not having to construct the box culvert, eliminating the risk of land subsidence, and not taking the soft soil improvement to achieve the allowable residual settlement and not affecting the surface flow across the research section. 


\section{Conclusions and Recommendations}

- The area of Phong Son commune, Phong Dien district, Thua Thien Hue province, has limestone bedrock. The presence of limestone is a favorable condition for the existence and development of the underground Karst space due to the chemical dissolution and washing of limestone into the fractured and cracked zones and is considered as the initial premise of the risk of land subsidence in the research section.

- Besides, researches in the world and in Vietnam show that the phenomenon of material from covered soil layers being swept into the underground karst space is very common, occurs suddenly and is the most dangerous form of the risk, while the ceiling collapsing of the underground Karst space is very rare and occurs for a very long time.

- The land subsidence will hardly occur without stimulating factors, mainly due to exogenous and endogenous causes such as: increase in water flow to the covered soil layers; groundwater level goes down; mining activities; change of the vegetation cover; noise; increase in static load due to construction works, dynamic load from vehicles, filling soil, and seasonal fluctuations of groundwater level, earthquake... However, most of the above-mentioned stimulating factors have not been identified clearly at the section from Km55+660 to Km55+690, so there is no firm basis to assess the influence of these factors on the possibility of the land subsidence at the research section, which should be continued study.

- Quantitative assessment results of the impact of embankment and vehicle loads on the possibility of land subsidence related to the underground Karst caves in the research section show that there is a risk of collapsing the cave ceiling. It is necessary to have solutions to prevent the risk of land subsidence.

- The calculated results show that the vertical displacement (settlement) of the ground is larger than the allowable residual settlement, it is necessary to take the soft soil improvement to achieve the allowable residual settlement.

- It is recommended to use flyover through the section with underground Karst caves. This is a solution with a high feasibility, not having to construct the box culvert, eliminating the risk of land subsidence, and not taking the soft soil improvement to achieve the allowable residual settlement and not affecting the surface flow across the research section.

\section{Acknowledgements}

This research is funded by the University of Transport and Communications (UTC) under grant number T2022-CT-027. The authors are very grateful to the reviewers, Editor in Chief Prof. Dr. Salih M. Awadh, the Secretary of Journal Mr. Samir R. Hijab, and the Technical Editors for their great efforts and valuable comments.

\section{References}

22 TCN 262-2000. Process of surveying and designing the embankment of expressways on soft soil. Ministry of Transport, Hanoi, 39 p (In Vietnamese).

Abdula, R. A., 2021. Speleology of Kospi Spi Cave in Northern Iraq. Iraqi Geological Journal, 54 (2A), 126-133. Awadh, S.M., Abood, Z.S. and Eisa, M.J., 2013. Chemical and physical control processes on the development of caves in the Injana Formation, Central Iraq. Arabian Journal of Geosciences, 6(10),.3765-3772.

Duc, d. M., Binh, N. V., 2012. Research on the formation mechanism of sinkholes in the underground Karst area; A case study in Cho Don area, Bac Kan province, Vietnam. Journal of Mining Geology Sciences, 38, 16-24.

Hung Nghiep Construction Consulting Limited Liability Company (HNCCLLC), 2020. Geotechnical investigation report for technical design of North-South Vietnam Expressway, Cam Lo - La Son section, Hanoi (In Vietnamese). 
Hung Nghiep Construction Consulting Limited Liability Company (HNCCLLC), 2021. Geotechnical imvestigation reports for detailed design and construction of North-South Vietnam Expressway, Cam Lo La Son section, Hanoi (In Vietnamese).

Institute of Geological Sciences, 2014. Research to identify causes and propose solutions to reduce land subsidence in Cam Pha city. Final report on scientific research proJECT, Hanoi, 147 pp.

Lam, D. H., Thinh, P. H., 2020. Study on mechanical properties of cracked rock mass at National Highway 3B in Bac Kan province by numerical method EFC. Final report on scientific research project, code T2020-CT-024. Publishing house of University of Transport and Communications, Hanoi, 66.

Manga \& Wang, 2015. Earthquake Hydrology. Treatise on Geophysics, Second Edition. Elsevier, Amsterdam,. 305-324.

Petar T. Milanovic, 2000. Geological Engineering in Karst. Zebra Publishing Ltd., Belgrade, 347 pp.

Son, B. T., Nu, N. T., Duong, N. T., Ngoc, N. A., 2020. Application the point foundation (PF) method for soft soil improvement: A case study from Vietnam. Iraqi Geological Journal, 53 (2D), 1-18.

Thinh, P. H., Nu, N. T., Thanh, P. T., 2020. Land subsidence in Cam Son region of Vietnam and the solutions to minimize its negative impacts to construction works. International Journal of Emerging Trends in Engineering Research, 8 (4),1011-1018.

Vietnam Institute of Geosciences and Mineral resources, 2005. Sustainable development of limestone areas in Vietnam, Hanoi, 32 p (In Vietnamese).

Waltham T., 2008. Sinkhole hazard case histories in karst terrains. Journal of Engineering Geology, 41, 291-300.

Waltham, T., Lu, Z., 2007. Natural and anthropogenic rock collapse over open caves. Geol Soc Spec Publ 279: 13-21. 